\title{
Evaluation of Dietary Hydrolyzed Barley on Growth Performance, Nutrient Digestibility, Blood Characteristic, and Meat Quality in Finishing Pigs
}

\author{
Lei Yan $^{1} \&$ I.H. Kim ${ }^{1}$ \\ ${ }^{1}$ Department of Animal Resource and Science, Dankook University, Choongnam Cheonan, Korea \\ Correspondence: Lei Yan, Department of Animal Resource and Science, Dankook University, Choongnam \\ Cheonan, 330-714, Korea. E-mail: nickyx666@hotmail.com
}

Received: September 3, 2012 Accepted: September 20, 2012 Online Published: November 15, 2012

doi:10.5539/jas.v4n12p285 URL: http://dx.doi.org/10.5539/jas.v4n12p285

This work was supported by a grant from the BioGreen 21 Program (No. PJ312036-3), Rural Development Administration, Republic of Korea

\begin{abstract}
A total of 144 [(Duroc $\times$ Yorkshire $) \times$ Landrace] pigs with an average initial BW of $61.8 \pm 1.04 \mathrm{~kg}$ were used in this 70 -d growth experiment. Pigs were allotted to 4 treatments based on their initial BW using a randomized complete block design. Each treatment consisted of 9 replications (pen) with 4 pigs per pen ( 2 gilts and 2 barrows). Dietary treatments were: 1) V0, 0\% hydrolyzed barley (HB) and 30\% de-hulled barley (DB); 2) V1, 10\% $\mathrm{HB}$ and $20 \% \mathrm{DB}$; 3 ) V2, $20 \% \mathrm{HB}$ and $10 \% \mathrm{DB}$; and 4$) \mathrm{V} 3,30 \% \mathrm{HB}$ and $0 \% \mathrm{DB}$. In this study, our analyzed data suggested that hydrolyzed barley increased the energy and CP concentration by $50.65 \%$ and $18 \%$, respectively, compared with the de-hulled barley. In the feeding trail, Pigs fed the V2 and V3 treatment diet increased $(\mathrm{P}<0.05)$ the $\mathrm{N}$ digestibility compared with the $\mathrm{V} 0$ treatment at the end of 5 week. An increased $(\mathrm{P}<0.10)$ tendency was also observed on the energy and nitrogen digestibility at the end of 5 week and 10 week, respectively. Moreover, pigs fed the HB diet tend to increase $(\mathrm{P}<0.10)$ the average daily gain $(\mathrm{ADG})$ and average daily feed intake (ADFI). The inclusion of V3 treatment decreased $(\mathrm{P}<0.05)$ the blood cholesterol compared with those contain DB. Dietary V3 treatment led to a higher $(\mathrm{P}<0.05)$ WHC than the V0 and V1 treatment. Pigs fed V2 and V3 treatment decreased $(\mathrm{P}<0.05) \mathrm{L}^{*}$ value compared with DB diet. In conclusion, the inclusion of hydrolyzed barley could improve the meat quality without any negative effect on the growth performance and nutrient digestibility, which provide a strong indication that hydrolyzed barley could be used as a good energy source for swine.
\end{abstract}

Keywords: de-hulled barley, finishing pig, hydrolyzed barely

\section{Introduction}

Barley (Hordeum vulgare L.) is widely used in pig diets primarily as an energy source now (C. W. Newman \& R. K. Newman, 2006). However, the growth performance of pigs fed barley based diets is generally inferior to those fed wheat or corn based diets because of the crude fiber in the hull fraction (Hollis \& Palmer, 1971; Bell et al., 1983). Previous study had confirmed that the possible way to increase the nutritive value of barley is the removal of the hull from barley (de-hulled barley; DB) (Wu et al., 2000). However, the poor yield and the fragility of the grain did not allow its development during last decades. Thus, it is necessary to develop a new method to improve the feeding value of barley.

Previously, Fry et al. (1957) had suggested that water-treatment of barley could improve its nutrient value, and confirmed that dietary water-treated barley could improve the growth performance in chicks. Recently, Etokakpan and Palmer (1990) has suggested that the cell walls of barley can be degraded extensively during malting compared with other grain. Jones (2005) also reviewed that the germination of barley could break down the seed biopolymers such as starch, protein and fiber. Therefore, it is interesting to investigate if hydrolyzed barley (HB) could be used as a potential material for the animal feedstuff.

To the best of our knowledge, this is the first study concern about the nutrition value of the innovative barley (HB) in pigs. Thus, our study was conducted to evaluate the feeding value of the HB in pigs. 


\section{Materials and Methods}

\subsection{Animal Use and Care}

This experiment was conducted at the Experimental Unit of Dankook University, with all protocols were approved by the Animal Care and Use Committee of Dankook University.

Table 1. Analyzed nutrient composition and energy content of hydrolyzed and de-hulled barley (as fed basis)

\begin{tabular}{|c|c|c|}
\hline Item & Hydrolyzed barley & De-hulled barley \\
\hline \multicolumn{3}{|l|}{ Chemical composition, $\%$} \\
\hline $\mathrm{DM}$ & 92.2 & 89.6 \\
\hline $\mathrm{CP}$ & 14.8 & 9.8 \\
\hline Crude fat & 2.21 & 2.10 \\
\hline Crude fiber & 9.86 & 5.60 \\
\hline Neutral detergent fiber & 29.8 & 19.9 \\
\hline Acid detergent fiber & 15.2 & 8.0 \\
\hline$\beta$-glucan & 2.16 & 7.38 \\
\hline Crude ashes & 4.17 & 2.40 \\
\hline $\mathrm{GE}, \mathrm{kcal} / \mathrm{kg}$ & 4210 & 3567 \\
\hline \multicolumn{3}{|l|}{ Indispensible AA, \% } \\
\hline $\operatorname{Arg}$ & 0.49 & 0.49 \\
\hline His & 0.54 & 0.25 \\
\hline Ile & 0.42 & 0.36 \\
\hline Leu & 1.30 & 0.68 \\
\hline Lys & 0.51 & 0.39 \\
\hline Met & 0.20 & 0.18 \\
\hline Phe & 0.64 & 0.49 \\
\hline Thr & 0.55 & 0.36 \\
\hline $\operatorname{Trp}$ & 1.55 & 0.29 \\
\hline Val & 0.67 & 0.52 \\
\hline \multicolumn{3}{|c|}{ Fatty acid, $\%$ total fatty acid } \\
\hline Myristic acids C14:0 & 1.20 & 1.21 \\
\hline Palmitic acid C16:0 & 20.1 & 22.1 \\
\hline Stearic acid C18:0 & 1.21 & 1.30 \\
\hline Oleic acid C18:1 & 10.3 & 12.5 \\
\hline Linoleic acid C18:2 & 67.0 & 52.7 \\
\hline Linolenic acid C18:3 & 5.92 & 6.20 \\
\hline \multicolumn{3}{|l|}{ Mineral composition } \\
\hline $\mathrm{Ca}, \%$ & 0.13 & 0.07 \\
\hline $\mathrm{P}, \%$ & 0.35 & 0.34 \\
\hline $\mathrm{K}, \%$ & 1.08 & 0.48 \\
\hline $\mathrm{Cl}, \%$ & 0.75 & 0.12 \\
\hline $\mathrm{Mg}, \%$ & 0.33 & 0.11 \\
\hline $\mathrm{Mn}, \mathrm{mg} / \mathrm{kg}$ & 19.6 & 16.0 \\
\hline $\mathrm{Zn}, \mathrm{mg} / \mathrm{kg}$ & 43.3 & 30.7 \\
\hline $\mathrm{Cu}, \mathrm{mg} / \mathrm{kg}$ & 4.54 & 9.54 \\
\hline $\mathrm{Fe}, \mathrm{mg} / \mathrm{kg}$ & 170 & 158 \\
\hline
\end{tabular}




\subsection{Preparation of De-Hulled Barley and Hydrolyzed Barley}

In the current study, both the DB and HB were provided by Designsolv Inc. (Guangzu, South Korea). Briefly, DB was processed by a full circle hammermill with a $2.5-\mathrm{mm}$ hammermill grind screen. HB was then produced in jars according to patent 10-08717830 (2006). Briefly, viable hulled barley grains were steeped in water (at a ratio of $1: 3(\mathrm{wt} / \mathrm{wt})$ ) as follows: $19 \mathrm{~h}$ wet at $15-18^{\circ} \mathrm{C}, 22 \mathrm{~h}$ air rest at $24^{\circ} \mathrm{C}, 16 \mathrm{~h}$ wet at $15-18^{\circ} \mathrm{C}, 4 \mathrm{~h}$ air rest at $24^{\circ} \mathrm{C}, 3 \mathrm{~h}$ wet at $55^{\circ} \mathrm{C}, 3 \mathrm{~h}$ wet at $60^{\circ} \mathrm{C}, 3 \mathrm{~h}$ wet at $65^{\circ} \mathrm{C}$, and air rest at $24^{\circ} \mathrm{C}$ until the moisture is less than $20 \%$, and then grind it to get the final HB. The chemical composition of HB and DB was analyzed in triplicate before initiation of the experiment (Table 1). The AA profiles (excluding tryptophan) were analyzed by Sykam Amino Acid Analyser (Laserchrom HPLC Laboratories Ltd. Inc., Rochester, UK) and HPLC after acid hydrolysis for 24h in $6 \mathrm{M} \mathrm{HCl}$ (AOAC, 2000; Laserchrom HPLC Laboratories Ltd. Inc., Rochester, UK). The chemical composition of HB was determined according to (AOAC, 1995) as follows: moisture (Method 930.15), CP (Method 990.03), crude fat (Method 920.39), crude fiber (Method 962.09), crude ash (Method 942.05), Ca (method 984.01), P (method 965.17). The acid detergent fiber and neutral detergent fiber were also determined according to Van Soest et al. (1991). The $\beta$-glucan content of the barley was determined using the Megazyme mixed-linkage $\beta$-glucan assay kit (Megazyme International Ireland Ltd.) developed by McCleary and Codd (1991). The gross energy was determined by measuring the heat of combustion in the samples using a Parr 6100 oxygen bomb calorimeter (Parr instrument Co., Moline, IL).

\subsection{Experimental Design, Animals, Housing and Diets}

A total of 144 [(Duroc $\times$ Yorkshire $) \times$ Landrace] pigs with an average initial BW of $61.8 \pm 1.04 \mathrm{~kg}$ were used in this 70-d growth trial. Pigs were allotted to 4 dietary treatments based on their initial BW using a randomized complete block design. Each treatment consisted of 9 replications with 4 pigs per pen ( 2 gilts and 2 barrows). Dietary treatments were: 1) V0, $0 \% \mathrm{HB}$ and $30 \% \mathrm{DB} ; 2$ ) V1, $10 \% \mathrm{HB}$ and $20 \% \mathrm{DB}$; 3) V2, $20 \% \mathrm{HB}$ and $10 \%$ $\mathrm{DB}$; and 4) V3, 30\% HB and 0\% DB. There was 2-d acclimation time prior to the experiment. All diets used in this experiment were formulated based on the analyzed value of HB and DB to meet or exceed NRC (1998) recommendations for all nutrients (Table 2). Diets were freeze-dried and ground finely to analyze acid detergent fiber and neutral detergent fiber (Van Soest et al., 1991), CP (Method 990.03), Ca (AOAC, 1995, method 984.01), P (method 965.17), $\beta$-glucan (McCleary \& Codd, 1991). The gross energy was determined by measuring the heat of combustion in the samples using a Parr 6100 oxygen bomb calorimeter (Parr instrument Co., Moline, IL). Amino acids were analyzed by Sykam Amnio Acid Analyser (Laserchrom HPLC Laboratories Ltd. Inc., Rochester, UK). Pigs were housed in an environmentally controlled, slatted-floor facility pens (1.8 $\times$ $1.8 \mathrm{~m}$ ) at the pig farm of Dankook University. All pigs were provided with ad libitum access to feed and water through a self-feeder and nipple drinker, respectively, throughout the experiment.

\subsection{Growth Performance and Nutrient Digestibility}

Body weight were measured on day 35 and 70 to monitor the average daily gain (ADG), feed consumption were also monitored to calculated average daily feed intake (ADFI) and gain/feed (G/F) ratio. Chromium oxide $\left(\mathrm{Cr}_{2} \mathrm{O}_{3}\right)$ was added to the diet at a level of $2 \mathrm{~g} / \mathrm{kg}$ as an indigestible marker during day 28-33, and 63-68 to determine the digestibility coefficient. Fecal grab samples were collected at random from at least two pigs in each pen on day 33 , and 68. All the feed and fecal samples were freeze-dried and finely ground to be able to pass through a 1-mm screen, and stored in a refrigerator at $-20^{\circ} \mathrm{C}$ until analysis. The $\mathrm{DM}$ and $\mathrm{N}$ concentrations were determined according to the AOAC (2000). Chromium levels were determined via UV absorption spectrophotometry (Shimadzu, UV-1201, Japan) following the method described by Williams et al. (1962). The coefficient of apparent total tract digestibility (CATTD) of DM and $\mathrm{N}$ were calculated using indirect-ratio methods using the following formula:

Coefficient of apparent total tract digestibility $=\{1-[(\mathrm{Nf} \times \mathrm{Cd}) /(\mathrm{Nd} \times \mathrm{Cf})]\}$, where $\mathrm{Nf}=$ nutrient concentration in feces $(\% \mathrm{DM}), \mathrm{Nd}=$ nutrient concentration in diet $(\% \mathrm{DM}), \mathrm{Cf}=$ chromium concentration in feces $(\% \mathrm{DM})$, and $\mathrm{Cd}=$ chromium concentration in feces $(\% \mathrm{DM})$.

\subsection{Blood Characteristics}

At the end of the $5^{\text {th }}$ and $10^{\text {th }}$ week, two pigs were randomly chosen from each pen and bled via jugular venipuncture to obtain blood samples. At each collection time, the blood samples were collected into a $\mathrm{K}_{3} \mathrm{EDTA}$ vacuum tube (Becton Dickinson Vacutainer Systems, Franklin Lakes, NJ). All blood samples were centrifuged for 30 minutes at $2,000 \times \mathrm{g}$ and $4^{\circ} \mathrm{C}$ to separate the serum, after which the $\mathrm{IgG}$ and cholesterol levels were assessed using an automatic biochemistry blood analyzer (HITACHI 747, Hitachi, Tokyo, Japan). The white 
blood cells (WBC), red blood cells (RBC), and lymphocyte counts were analyzed using an automatic blood analyser (ADVIA 120, Bayer, NY).

Table 2. Composition of basal finishing pig diets (as-fed basis)

\begin{tabular}{|c|c|c|c|c|}
\hline & V0 & V1 & V2 & V3 \\
\hline $\mathrm{HB}^{1}, \%$ & 0 & 10 & 20 & 30 \\
\hline $\mathrm{DB}^{1}, \%$ & 30 & 20 & 10 & 0 \\
\hline Corn & 31.34 & 31.34 & 31.34 & 31.34 \\
\hline De-hull Barley & 30.0 & 20.0 & 10.0 & 0.0 \\
\hline Hydralated barley & 0.0 & 10.0 & 20.0 & 30.0 \\
\hline Soybean meal & 15.36 & 15.36 & 15.36 & 15.36 \\
\hline DDGS & 5.00 & 5.00 & 5.00 & 5.00 \\
\hline Wheat & 5.00 & 5.00 & 5.00 & 5.00 \\
\hline Rice bran & 3.00 & 3.00 & 3.00 & 3.00 \\
\hline Limestone & 0.63 & 0.63 & 0.63 & 0.63 \\
\hline Tallow & 4.63 & 4.63 & 4.63 & 4.63 \\
\hline Molasses & 3.00 & 3.00 & 3.00 & 3.00 \\
\hline Salt & 0.30 & 0.30 & 0.30 & 0.30 \\
\hline L-Lys (94\%) & 0.26 & 0.26 & 0.26 & 0.26 \\
\hline${ }_{\mathrm{DL}}-\operatorname{Met}(98 \%)$ & 0.02 & 0.02 & 0.02 & 0.02 \\
\hline Dicalcium Phosphate Dihydrate & 1.05 & 1.05 & 1.05 & 1.05 \\
\hline Vitamin-mineral premix ${ }^{2}$ & 0.41 & 0.41 & 0.41 & 0.41 \\
\hline \multicolumn{5}{|l|}{ Analyzed composition } \\
\hline $\mathrm{GE}, \mathrm{kcal} / \mathrm{kg}$ & 4185 & 4257 & 4342 & 4415 \\
\hline $\mathrm{CP}, \%$ & 15.3 & 15.4 & 16.1 & 16.5 \\
\hline Lys, \% & 0.93 & 0.95 & 0.96 & 0.97 \\
\hline Crude fiber, $\% \mathrm{DM}$ & 2.28 & 2.71 & 3.23 & 3.56 \\
\hline Neutral detergent fibre, $\%$ DM & 26.7 & 27.6 & 28.6 & 29.6 \\
\hline Acid detergent fibre, \% DM & 13.1 & 13.8 & 14.5 & 15.3 \\
\hline$\beta$-glucan, \% DM & 3.93 & 3.41 & 2.89 & 2.37 \\
\hline $\mathrm{Ca}, \%$ & 0.74 & 0.75 & 0.75 & 0.76 \\
\hline Total P, \% & 0.62 & 0.63 & 0.64 & 0.64 \\
\hline
\end{tabular}

${ }^{1} \mathrm{HB}=$ hydrolyzed barley; $\mathrm{B}=$ de-hulled barley.

${ }^{2}$ Provided per kg of complete diet: vitamin A, 9,000 IU; vitamin $\mathrm{D}_{3}, 1,200 \mathrm{IU}$; vitamin E, $40 \mathrm{IU}$; vitamin $\mathrm{K}, 3.0 \mathrm{mg}$; vitamin $\mathrm{B}_{2}, 5.2 \mathrm{mg}$; vitamin $\mathrm{B}_{6}, 2.6 \mathrm{mg}$; vitamin $\mathrm{B}_{12}, 26 \mu \mathrm{g}$; niacin, $32 \mathrm{mg}$; $\mathrm{d}$-pantothenic acid (as d-calcium pantothenate), $20 \mathrm{mg}$; Provided per kg of complete diet: $\mathrm{Cu}\left(\right.$ as $\left.\mathrm{CuSO}_{4} \cdot 5 \mathrm{H}_{2} \mathrm{O}\right), 15 \mathrm{mg} ; \mathrm{Fe}\left(\right.$ as $\left.\mathrm{FeSO}_{4} \cdot 7 \mathrm{H}_{2} \mathrm{O}\right), 70 \mathrm{mg}$; $\mathrm{Zn}\left(\right.$ as $\mathrm{ZnSO}_{4}$ ), $50 \mathrm{mg}$; $\mathrm{Mn}\left(\mathrm{MnO}_{2}\right), 50 \mathrm{mg}$; I (as $\mathrm{KI}$ ), $0.5 \mathrm{mg}$; Co (as $\mathrm{CoSO}_{4} \cdot 5 \mathrm{H}_{2} \mathrm{O}$ ), $0.3 \mathrm{mg}$; and $\mathrm{Se}$ (as $\left.\mathrm{Na}_{2} \mathrm{SeO}_{3} \cdot 5 \mathrm{H}_{2} \mathrm{O}\right), 0.2 \mathrm{mg}$.

\subsection{Meat Quality}

At the end of the experiment, all the pigs were slaughtered at a local commercial slaughterhouse. A 2.5 -cm-thick section of longissimus muscle was removed from the center (in the region of the 10th rib) of a boneless pork loin. After chilling at $2^{\circ} \mathrm{C}$ for at least $24 \mathrm{~h}$, the meat samples were thawed at ambient temperature prior to evaluation. Sensory evaluation (color, marbling and firmness scores) was conducted according to the National Pork Producers Council Standards (NPPC, 2000). Immediately after the subjective tests were conducted, the lightness 
$\left(\mathrm{L}^{*}\right)$, redness $\left(\mathrm{a}^{*}\right)$ and yellowness $\left(\mathrm{b}^{*}\right)$ values were measured at 3 locations on the surface of each sample using a Model CR-410 Chroma meter (Konica Minolta Sensing, Inc., Osaka, Japan). At the same time, duplicate pH measurements of each sample were taken directly using a $\mathrm{pH}$ meter (Pittsburgh, PA, USA). The longissimus muscle (LM) area was measured by tracing the surface of the LM at the 10th rib, which was also conducted using a digitizing area-line sensor (MT-10S; M.T. Precision Co. Ltd., Tokyo, Japan). The 2-Thiobarbituric acid reactive substances (TBARS) were measured using $5 \mathrm{~g} \mathrm{LM}$ according to the method described by Witte et al. (1970). The TBARS values were expressed in terms of milligrams of malonaldehyde per kilogram of muscle. Trichloroacetic acid solution (TCA, $20 \% \mathrm{wt} / \mathrm{vol}$ ) was utilized for the extraction. UV absorption spectrophotometry (UV-1201, Shimadzu, Japan) was employed for the spectrohoptometric analyses.

\subsection{Statistical Analyses}

All the data were pooled and statistically analyzed by ANOVA using GLM procedures of SAS as a randomized complete block design (SAS Inst. Inc., Cary, NC), with the pen servers as the experimental unit. The initial model included the dietary treatment and block effects, but no effect of the block were detected. Therefore, period effect was removed from the model. The difference among treatments was compared using the fisher's LSD test. Variability in the data was expressed as SE, probability values less than 0.05 were considered significant, while the probability value less than 0.10 were considered as a tendency.

\section{Results}

\subsection{Analyzed Value of the $H B$ and $D B$}

Our analyzed data suggested the hydrolyzed barley increased the energy and CP concentration to $14.87 \%$ and 4210 $\mathrm{kcal} / \mathrm{kg}$ (Table 1), which is about 50.65 and $18 \%$ higher than those in DB, respectively. Most of the essential amino acid in HB is higher than those in DB.

\subsection{Growth Performance and Nutrient Digestibility}

In our study, dietary HB tended to increase $(\mathrm{P}<0.10)$ the $\mathrm{ADG}$ at 5 week and the overall period (Table 3$)$. We also noticed that $\mathrm{HB}$ tended to increase $(\mathrm{P}<0.10)$ feed intake at 5 week. No difference was observed on the G:F ratio throughout the experiment. Pigs fed the V2 and V3 treatment diet increased $(\mathrm{P}<0.05)$ the $\mathrm{N}$ digestibility compared with the $\mathrm{V} 0$ treatment at the end of 5 week (Table 4$)$. The inclusion of HB tended to increase $(\mathrm{P}<0.10)$ the energy and nitrogen digestibility at the end of 5 week and 10 week, respectively.

Table 3. Effect of VAW on growth performance in finishing pigs ${ }^{1}$

\begin{tabular}{ccccccc}
\hline Item & $\mathrm{V}^{1}$ & $\mathrm{~V}^{1}$ & $\mathrm{~V}^{1}$ & $\mathrm{~V}^{1}$ & $\mathrm{SE}^{2}$ & P-Value \\
\hline \multicolumn{2}{c}{0 to 5 week } & & & & & \\
ADG, g & 705 & 726 & 746 & 745 & 21 & 0.064 \\
ADFI, g & 2,192 & 2,213 & 2,226 & 2,231 & 50 & 0.079 \\
G/F & 0.322 & 0.328 & 0.335 & 0.334 & 0.010 & 0.215 \\
5 to 10 week & & & & & \\
ADG, g & 794 & 827 & 830 & 823 & 34 & 0.175 \\
ADFI, g & 2,582 & 2,617 & 2,625 & 2,655 & 128 & 0.236 \\
G/F & 0.308 & 0.316 & 0.316 & 0310 & 0.022 & 0.352 \\
0 to 10 week & & & & & \\
ADG, g & 750 & 777 & 788 & 784 & 23 & 0.089 \\
ADFI, g & 2,387 & 2,415 & 2,426 & 2,443 & 79 & 0.123 \\
G/F & 0.314 & 0.322 & 0.325 & 0.321 & 0.014 & 0.278
\end{tabular}

${ }^{1}$ Abbreviation: VAW0, 0\% hydrolyzed barley (HB) and 30\% de-hulled barley (DB); VAW10, 10\% HB and 20\% DB; VAW20, 20\% HB and 10\% DB; and VAW30, 30\% HB and $0 \%$ DB.

${ }^{2}$ Standard error. 
Table 4. Effect of VAW on nutrient digestibility in finishing pigs ${ }^{1}$

\begin{tabular}{lcccccc}
\hline Items, \% & $\mathrm{V}^{1}$ & $\mathrm{~V}^{1}$ & $\mathrm{~V}^{1}$ & $\mathrm{~V}^{1}$ & $\mathrm{SE}^{2}$ & P-value \\
\hline Dry matter & & & & & & \\
5 week & 73.4 & 75.5 & 74.7 & 74.5 & 1.85 & 0.212 \\
10 week & 71.3 & 72.3 & 73.9 & 75.9 & 1.60 & 0.351 \\
Nitrogen & & & & & & \\
5 week & $67.5^{\mathrm{b}}$ & $69.6^{\mathrm{ab}}$ & $71.8^{\mathrm{a}}$ & $73.1^{\mathrm{a}}$ & 1.71 & 0.025 \\
10 week & 69.0 & 69.4 & 71.6 & 72.1 & 1.96 & 0.084 \\
Energy & & & & & & \\
5 week & 73.4 & 74.1 & 74.3 & 76.6 & 1.64 & 0.071 \\
10 week & 74.4 & 75.3 & 74.4 & 74.5 & 0.87 & 0.215 \\
\hline
\end{tabular}

${ }^{1}$ Abbreviation: VAW0, $0 \%$ hydrolyzed barley (HB) and 30\% de-hulled barley (DB); VAW $10,10 \%$ HB and 20\% DB; VAW20, 20\% HB and 10\% DB; and VAW30, 30\% HB and $0 \%$ DB.

${ }^{2}$ Standard error

\subsection{Blood Characteristics}

Pigs fed the V3 treatment diet decreased $(\mathrm{P}<0.05)$ the cholesterol concentration compared with those fed DB diets (Table 5). No difference $(\mathrm{P}>0.05)$ was observed on the other characteristics investigated in the current study.

Table 5. Effect of VAW on blood characteristics in finishing pigs ${ }^{1}$

\begin{tabular}{lllllll}
\hline Items & $\mathrm{V}^{1}$ & $\mathrm{~V}^{1}$ & $\mathrm{~V}^{1}$ & $\mathrm{~V}^{1}$ & $\mathrm{SE}^{2}$ & P-value \\
\hline Total cholesterol, $\mathrm{mg} / \mathrm{dL}$ & & & & & \\
0 week & 94 & 92 & 92 & 94 & 3.1 & 0.225 \\
5 week & 93 & 88 & 83 & 88 & 5.2 & 0.102 \\
10 week & $114^{\mathrm{a}}$ & $102^{\mathrm{ab}}$ & $97^{\mathrm{ab}}$ & $91^{\mathrm{b}}$ & 5.1 & 0.035 \\
IgG, mg/dL & & & & & & \\
0 week & 790 & 762 & 862 & 858 & 66.2 & 0.361 \\
5 week & 947 & 986 & 1,047 & 1,037 & 97.4 & 0.146 \\
10 week & 1,057 & 1,147 & 1,175 & 1,180 & 74.2 & 0.123 \\
RBC, $10^{6} / \mathrm{mm}$ & & & & & & \\
0 week & 6.13 & 6.29 & 6.18 & 6.24 & 0.20 & 0.352 \\
5 week & 6.21 & 6.31 & 6.38 & 6.47 & 0.18 & 0.221 \\
10 week & 6.35 & 6.44 & 6.49 & 6.49 & 0.19 & 0.126 \\
WBC, $10^{3} / \mathrm{mm}$ & & & & & & \\
0 week & 16.7 & 16.7 & 16.6 & 18.9 & 1.32 & 0.268 \\
5 week & 16.7 & 17.9 & 17.5 & 18.1 & 1.49 & 0.096 \\
10 week & 17.9 & 18.5 & 19.1 & 19.4 & 1.08 & 0.214 \\
Lymphocyte, $\%$ & & & & & & \\
0 week & 56.9 & 55.7 & 55.5 & 59.8 & 2.31 & 0.152 \\
5 week & 57.6 & 56.8 & 60.8 & 57.3 & 2.71 & 0.321 \\
10 week & 58.9 & 57.8 & 63.8 & 57.7 & 3.27 & 0.189 \\
\hline
\end{tabular}

${ }^{1}$ Abbreviation: VAW0, 0\% hydrolyzed barley (HB) and 30\% de-hulled barley (DB); VAW10, 10\% HB and $20 \%$ DB; VAW20, 20\% HB and 10\% DB; and VAW30, 30\% HB and $0 \%$ DB.

${ }^{2}$ Standard error. 


\subsection{Meat Quality}

Pig fed V3 treatment led to a higher $(\mathrm{P}<0.05)$ WHC than the V0 and V1 treatment (Table 6). Dietary V2 and V3 treatment decreased $(\mathrm{P}<0.05) \mathrm{L} *$ value compared with $\mathrm{DB}$ diet. No difference $(\mathrm{P}>0.05)$ was observed on the other criteria in the current study.

Table 6. Effect of VAW on meat quality in finishing pigs

\begin{tabular}{|c|c|c|c|c|c|c|}
\hline Items & $\mathrm{V}^{1}$ & $\mathrm{~V} 1^{1}$ & $\mathrm{~V} 2^{1}$ & $\mathrm{~V}^{1}{ }^{1}$ & $\mathrm{SE}^{2}$ & P-value \\
\hline \multicolumn{7}{|c|}{ Sensory evaluation $^{3}$} \\
\hline Color & 2.58 & 2.74 & 2.63 & 2.67 & 0.148 & 0.215 \\
\hline Marbling & 2.13 & 2.17 & 2.15 & 2.20 & 0.131 & 0.341 \\
\hline Firmness & 1.85 & 1.79 & 1.82 & 1.81 & 0.157 & 0.521 \\
\hline \multicolumn{7}{|l|}{ Meat color ${ }^{4}$} \\
\hline $\mathrm{L}^{*}$ (lightness) & $56.5^{\mathrm{a}}$ & $55.4^{\mathrm{ab}}$ & $53.2^{\mathrm{b}}$ & $51.8^{\mathrm{b}}$ & 1.436 & 0.012 \\
\hline$a^{*}$ (redness) & 15.7 & 15.4 & 16.3 & 15.6 & 0.215 & 0.248 \\
\hline $\mathrm{b}^{*}$ (yellowness) & 7.34 & 7.28 & 7.17 & 7.25 & 0.387 & 0.168 \\
\hline Cooking loss, $\%$ & 23.4 & 23.2 & 22.8 & 23.6 & 0.418 & 0.305 \\
\hline $\mathrm{pH}$ at $24 \mathrm{~h}$ & 5.73 & 5.68 & 5.74 & 5.76 & 0.054 & 0.184 \\
\hline $\mathrm{WHC}^{5}, \%$ & $41.2^{\mathrm{b}}$ & $42.3^{\mathrm{b}}$ & $44.8^{\mathrm{ab}}$ & $46.5^{\mathrm{a}}$ & 2.015 & 0.007 \\
\hline $\mathrm{LMA}^{6}, \mathrm{~cm}^{2}$ & 41.4 & 42.2 & 42.0 & 41.4 & 0.689 & 0.164 \\
\hline
\end{tabular}

${ }^{1}$ Abbreviation: VAW0, 0\% hydrolyzed barley (HB) and 30\% de-hulled barley (DB); VAW10, 10\% HB and 20\% DB; VAW20, 20\% HB and 10\% DB; and VAW30, 30\% HB and $0 \%$ DB.

${ }^{2}$ Standard error.

${ }^{3}$ According to the NPPC (2000) that is determined on a freshly-cut surface on the color scale of 1 to 5), Firmness ( 3 or greater on the scale of 1 to 5), Marbling ( 3 or greater on the scale of 1 to 5).

${ }^{4} \mathrm{~L} *$ indicates lightness, $a *$ indicates redness, $\mathrm{b} *$ indicates yellowness.

${ }^{5}$ Water holding capacity.

${ }^{6}$ Loin muscle area.

${ }^{\mathrm{a}, \mathrm{b}}$ means in the same row with different superscripts $\operatorname{differ}(\mathrm{P}<0.05)$.

\section{Discussion}

Generally, barley contains a highly viscous non-starch polysaccharide (NSP) (Skendi et al., 2003), which is evident to inhibit the nutrient utilization in monogastric animals (Ball et al., 2010). Bell et al. (1983) had reported that there is a large proportion of crude fiber in the hull fraction of barley. Therefore, it was a good method to remove the hull from barley to increase its nutritive value. However, because of the poor yield and the fragility of the grain, the use of DB in swine diets has been rather limited. In our study, we found the energy and crude protein levels of HB much higher than those of the DB, indicating the hydrolysis resulted in a higher nutrient value than the de-hulled barley. Moreover, HB appeared to have an increased content of essential amino acids compared with the DB, which is in line with Etokakpan and Palmer (1990) and Jones (2005), who suggested that malting process could produce various hydrolases in large quantities. However, it should be noted that the crude fiber of the HB is still higher than the DB, indicating the hydrolysis could not completely degrade the fiber that comparable to the de-hulled barley.

In the feeding trail, analyzed composition of the experimental diets suggested that the inclusion of HB increased the energy and crude protein content relative to those with DB. Thus, we hypothesized that pigs fed the HB diet could result in a better performance than the DB diet. Indeed, feeding HB diet increased the N digestibility at the end of 5 week, which reflects the higher nutrient value of HB in comparison to the DB. However interestingly, only an increased tendency was observed on the ADG with the inclusion of HB at 5 week and the overall period, whereas the inclusion of HB did not affect the growth performance during 5-10 week. It should be noted that 
dietary HB tended to increase feed intake during 0-5 weeks, whereas the inclusion of HB did not affect the feed intake during 5-10 weeks. Therefore, we hypothesized the reason for the increased tendency effect on growth performance could be the increased feed intake compared with those with DB diet. Collectively, our results indicated that the HB had a similar or better effect in comparison to the DB.

In terms of the blood characteristic, reduced blood cholesterol was observed with the HB diet compared with DB diets. Cholesterol is obtained directly from the diet, or synthesized in cells from 2 carbon acetate groups of acetyl-coenzymes A. Ponte et al. (2004) had previously suggested that the synthetic pathway is under feedback control from dietary cholesterol and the cholesterol arising from de novo biosynthesis; they also suggested that the de novo biosynthesis will produce enough cholesterol to supply the biological processes even when the cholesterol intake is very low. Therefore, the direct alteration of the cholesterol biosynthetic pathway would enable an alternation of the cholesterol. Kesanniemi et al. (1990) had previously suggested that fiber may block the absorption of fat from the digestive tract and reduce cholesterol synthesis in the liver. Umaru et al. (2003) also suggested that dietary fiber could interrupt the absorption of cholesterol in the small intestine, and reduce the cholesterol absorption. In our study, analyzed value of the experimental diets suggested that the fiber content is increased with the increasing level of HB. Therefore, the reason for the reduced cholesterol could be the higher fiber content of the diet containing HB than those with DB.

The inclusion of the HB increased the WHC and decreased $\mathrm{L}^{*}$ value, indicating the meat quality is positively affected by the HB supplementation. It has been suggested that WHC and $\mathrm{L}^{*}$ could be affected by various biochemical processes during the post-slaughter period. Several studies also suggested that the higher muscle glycogen levels at slaughter could decrease water-holding capacity in pigs (Miller et al., 2000; Hamilton et al., 2003). In the current study, the fiber content of the HB diet is higher than those with DB diets. Therefore, the reason for the higher WHC could be the increased muscle glycogen due to the higher fiber content. This conclusion is supported by Rosenvold et al. (2001) and Ruusumen et al. (2007), who reported that replacing starch-rich cereals in finishing diets with fiber-rich feed stuffs could increase the muscle glycogen deposition. In terms of the $\mathrm{L}^{*}$ value, Partanen et al. (2003) had previously suggested that higher fibrous diets could decrease the lightness of the longissimus muscle. Their recent study also confirmed that fibrous rich finishing diet darkened the color of the semispinalis captitis muscle (Partanen et al., 2007). Therefore, the decreased $L^{*}$ value could also be attributed to the higher fiber content in the HB diet. To the best of our knowledge, this is the first study conducted to evaluate this $\mathrm{HB}$, further studies is still warrant to investigate the mechanism underline.

\section{Conclusion}

In conclusion, our results suggested that the inclusion of hydrolyzed barley could benefit the meat quality without any negative effect on the growth performance and nutrient digestibility, which provide a strong indication that hydrolyzed barley is superior to the de-hulled barley as an energy source for swine.

\section{References}

AOAC. (1995). Official Method of Analysis. 16th ed. Assoc. Off. Analysis Chemistry, Washington, D.C.

AOAC. (2000). Official Methods of Analysis. 17th ed. Assoc. Off. Analysis Chemistry, Gaithersburg, M.D.

Ball, M. E. E., Mcevoy, J. D. G., \& McCracken, K. J. (2010). A note on the effect of the composition of barley produced at different locations on performance of growing pigs. Irish Journal of Agriculture and Food Research, 49, 87-92.

Bell, J. M., Shires, A., \& Keith, M. O. (1983). Effect of hull and protein contents of barley on protein and energy digestibility and feeding value for pigs. Canadian Journal of Animal Science, 63, 201-211. http://dx.doi.org/10.4141/cjas83-023

Etokakpan, O. U., \& Palmer, G. H. (1990). Comparative studies of the development of endosperm-degrading enzymes in malting sorghum and barley. World Journal of Microbiology and biotechnology, 6, 408-417. http://dx.doi.org/10.1007/BF01202124

Fry, R. E., Allred, J. B., Jensen, L. S., \& McGinnis, J. (1957). Influence of water-treatment on nutritional value of barley. Process Society for Experimental Biology aand Medicine, 95, 249-251.

Hamilton, D. N., Miller, K. D., Elis, M., McKeith, F. K., \& Wilson, E. R. (2003). Relationships between longissimus glycolytic potential and swine growth performance, carcass traits, and pork quality. Journal of Animal Science, 81, 2206-2212.

Hollis, G. R., \& Palmer, A. Z. (1971). Wheat and barley vs corn for growing-finishing pigs. Journal of Animal Science, 32, 381, (Abstract). 
Jones, B. L. (2005). Endoproteases of barley and malt. Journal of Cereal Science, 42, 139-156. http://dx.doi.org/10.1016/j.jcs.2005.03.007

Kesanniemi, Y. A., Tarpila, S., \& Miettinen, R. A. (1990). Low vs high dietary fiber and serum, biliary and faecal lipids in middle-aged men. American Journal of Clinical Nutrition, 51, 1007-12.

McCleary, B. V., \& Codd, R. (1991). Measurement of (1-3) (1-4)- $\beta$-glucan in barley and oats: a streamlined enzymic procedure. Journal of the Science of Food and Agriculture, 55, 303-312. http://dx.doi.org/10.1002/jsfa.2740550215

Miller, K. D., Ellis, M., Bidner, B., \& McKeith, F. K. (2000). Porcine longissimus glycolytic potential level effects on growth performance, carcass, and meat quality characteristics. Journal of Muscle and Foods, 11, 169-181. http://dx.doi.org/10.1111/j.1745-4573.2000.tb00423.x

Newman, C. W., \& Newman, R. K. (2006). A brief history of barley foods. Cereal Foods World, 51, 4-7.

NRC. (1998). Nutrient Requirements of Swine (10th ed). Washington, DC: Natl. Acad. Press.

NPPC. (2000). Composition and Quality Assessment Procedures. In E. Berg (Ed.), Natl. Pork Prod. Counc., Des Moines, IA.

Partanen, K., Alaviuhkola, T., Siljander-Rasi, H., \& Suomi, K. (2003). Faba beans in diets for growing-finishing pigs. Agriculture and Food Science, 12, 35-47.

Partanen, K., Siljander-Rasi, H., Honkavaara, M., \& Ruusunen, M. (2007). Effect of finishing diet and pre-slaughter fasting time on meat quality in crossbred pigs. Agriculture and Food Science, 16, 245-258. http://dx.doi.org/10.2137/145960607783328182

Ponte, P. I. P., Mendes, I., Quaresma, M., Aguiar, M. N. M., Lemos, J. P. C., Ferreira, L. M. A., ... Fontes, C. M. G. A. (2004). Cholesterol levels and sensory characteristic of meat form broilers consuming moderate to high levels of alfalfa. Poultry Science, 83, 810-814.

Rosenvold, K., Petersen, J. S., Lærke, H. N., Jensen, S. K., Therkildsen, M., Karlsen, A. H., ... Andersen, H. J. (2001). Muscle glycogen stores and meat quality as affected by strategic finishing feeding of slaughter pigs. Journal of Animal Science, 79, 382-391.

Ruusunen, M., Partanen, K., Pösö, R., \& Puolanne, E. (2007). The effect of dietary protein supply on carcass composition, size off organs, muscle properties and meat quality of pigs. Livestock Science, 107, 170-181. http://dx.doi.org/10.1016/j.livsci.2006.09.021

Skendi, A., Biliaderis, C. G., Lazaridou, A., \& Izydorczyk, M. S. (2003). Structure and rheological properties of water soluble B-glucans from oat cultivars of Avena sativa and Avena bysantina. Journal of Cereal Science, 38, 15-31. http://dx.doi.org/10.1016/S0733-5210(02)00137-6

Umaru, H. A., Umaru, I. J., \& Dahiru, D. (2003). Studies on taurocholate binding capacity and water holding capacity of variety of foodstuffs. Bioscience Research Communication, 15, 267-71.

Van Soest, P. J, Robertson, J. B., \& Lewis, B. A. (1991). Methods for dietary fiber, neutral detergent fiber and non-starch polysaccharides in relation to animal nutrition. Journal of Dairy Science, 74, 3583-3597. http://dx.doi.org/10.3168/jds.S0022-0302(91)78551-2

Williams, C. H., David, D. J., \& Iismaa, O. (1962). The determination of chromic oxide in faeces samples by atomic absorption spectrophotometry. Journal of Agriculture Science, 59, 381-385. http://dx.doi.org/10.1017/S002185960001546X

Witte, V. C., Krause, G. F., \& Bailey, M. E. (1970). A new extraction method for determining 2-thiobarbituric acid values for pork and beef during storage. Journal of Food Science, 35, 585-592. http://dx.doi.org/10.1111/j.1365-2621.1970.tb04815.x

Wu, J. F., Cheng, C. S., Yu, I. T., \& Hsyu, J. N. (2000). Hulless barley as an alternative energy source for growing-finishing pigs on growth performance, carcass quality, and nutrient digestibility. Livestock Production Science, 65, 155-160. http://dx.doi.org/10.1016/S0301-6226(99)00168-2 